\title{
Effects of CD20+ B-cell infiltration into allografts on kidney transplantation outcomes: a systematic review and meta- analysis
}

\author{
Yingying Lu ${ }^{1, *}$, Bingjue $\mathrm{Li}^{1, *}$, Qixia Shen ${ }^{1}$, Rending Wang ${ }^{1}$, Zhimin Chen ${ }^{1}$, Hong \\ Jiang ${ }^{1}$ and Jianghua Chen ${ }^{1}$ \\ ${ }^{1}$ Kidney Disease Center, The First Affiliated Hospital, College of Medicine, Zhejiang University, 310003, P.R. China \\ * These authors have contributed equally to this work \\ Correspondence to: Jianghua Chen, email: chenjianghua@zju.edu.cn \\ Hong Jiang, email: annie.jh@163.com \\ Keywords: CD20+ B cell, kidney transplantation, acute rejection, graft loss, steroid resistance \\ Received: September 23, $2016 \quad$ Accepted: March 04, $2017 \quad$ Published: March 15, 2017 \\ Copyright: Lu et al. This is an open-access article distributed under the terms of the Creative Commons Attribution License (CC-BY), which \\ permits unrestricted use, distribution, and reproduction in any medium, provided the original author and source are credited.
}

\section{ABSTRACT}

The effects of CD20+ B-cell infiltration during acute rejection on graft outcomes are controversial. The objective of this systematic review and meta-analysis was to clarify this issue. We performed a systematic literature search for studies published up to January 14, 2016. A total of 5 studies, with 200 patients, were included. The presence of CD20+ $\mathrm{B}$ cells in renal biopsies during allograft rejection was associated with graft loss and steroid resistance. No association of CD20+ B-cell infiltration with C4d-positive staining of the peritubular capillaries in renal biopsies was found in the analysis of patients who experienced kidney graft rejection. In conclusion, CD 20+ $B$ cell infiltration during allograft rejection was associated with an increased risk of graft loss and steroid resistance.

\section{INTRODUCTION}

Acute rejection can lead to chronic allograft nephropathy (CAN) and graft loss and can exacerbate organ shortages by resulting in re-transplantation [1]. Current immunosuppressive treatments for post-transplant management mainly focus on T-cell pathways. This has decreased the incidence of acute rejection. However, there is still a phenotype of acute rejection that is more recalcitrant to conventional treatment. This indicates that other mechanisms may be involved in this process.

Sarwal et al. detected B lymphocyte gene expression and $\mathrm{CD} 20+$ B-cell infiltration in kidney allograft biopsies, suggesting the potentially pathogenic role of B lymphocytes in acute renal rejection [2]. However, the relationship between $\mathrm{CD} 20+\mathrm{B}$ cells and the clinical outcome of acute rejection remains controversial. Several studies support the idea that the infiltration of CD20+ B cells during allograft rejection is associated with higher serum creatinine levels, steroid resistance or poor graft survival [2-8]. In many other studies, however, no impact of $\mathrm{CD} 20+$ cells on refractory rejection or graft outcome has been found [9-13]. Furthermore, some studies have linked CD20+ B cells with a favorable clinical prognosis [14].

Therefore, we performed a meta-analysis to verify whether the presence of $\mathrm{CD} 20+\mathrm{B}$ cells in renal biopsies could be a predictive marker for worse allograft outcomes after transplant rejection.

\section{RESULTS}

Literature search results and study characteristics

A total of 1537 potentially relevant citations were identified according to the search strategy. Of these citations, 1461 were excluded after their titles and abstracts were screened, leaving 76 studies for a fulltext assessment. Examples of the potential citations that were rejected from the second screening are provided in Supplementary Table 3. Finally, a total of 5 eligible studies, including200 study subjects, were analyzed $[2,4$, $6,7,9$ ] (Figure 1). 
Table 1: Characteristics of the studies included in the meta-analysis

\begin{tabular}{|c|c|c|c|c|c|c|c|c|c|}
\hline Study & $\begin{array}{c}\text { Number } \\
\text { of } \\
\text { patients }^{\mathrm{a}}\end{array}$ & $\begin{array}{c}\text { Age of } \\
\text { biopsy } \\
(\mathbf{y r})^{\mathrm{a}}\end{array}$ & Male $(\%)^{\mathrm{a}}$ & $\underset{\mathrm{a}}{\operatorname{DCD}(\%)}$ & $\operatorname{DGF}(\%)^{\mathrm{a}}$ & $\begin{array}{c}\text { Time } \\
\text { to AR } \\
\text { (month) }\end{array}$ & $\begin{array}{l}\text { Follow- } \\
\text { up }(y r)^{a}\end{array}$ & Patients & $\begin{array}{c}\text { Definition of } \\
\text { CD } 20 \text { positive/ } \\
\text { negative }^{\mathrm{a}}\end{array}$ \\
\hline $\begin{array}{l}\text { Bagnasco et al . } \\
2007\end{array}$ & $28 / 28$ & $49 / 44$ & $75.0 / 60.7$ & NA & $32.1 / 46.4$ & $2.7 / 2.5$ & $\begin{array}{|ll|}\text { at least } \\
4 \mathrm{yr}\end{array}$ & \begin{tabular}{|l|} 
first year ACR \\
I-II(Banff 97) \\
\end{tabular} & $\begin{array}{l}\geq 100 / \mathrm{HPF} \\
<50 / \mathrm{HPF} \\
\end{array}$ \\
\hline $\begin{array}{l}\text { Hippen et al. } \\
2005\end{array}$ & $6 / 21$ & $40 / 41$ & $66.7 / 61.9$ & $83.3 / 66.7$ & $100.0 / 100.0$ & $4.1 / 6.1$ & $\begin{array}{l}\text { at least } \\
4 \mathrm{yr}\end{array}$ & \begin{tabular}{|l|} 
first year ACR \\
IA-IB(Banff \\
97) \\
\end{tabular} & $\begin{array}{l}\text { strong and diffuse/ } \\
\text { trace or rare }\end{array}$ \\
\hline $\begin{array}{l}\text { Hwang et al. } \\
2010\end{array}$ & $23 / 31$ & $37 / 40$ & 69.6/48.4 & $4.3 / 22.6$ & $8.7 / 12.9$ & NA & $3.6 / 4.2$ & \begin{tabular}{|l|} 
first time ACR \\
I-II(Banff 97) \\
\end{tabular} & \begin{tabular}{|l}
$\geq 275 / \mathrm{HPF}$ \\
$\mid<100 / \mathrm{HPF}$ \\
\end{tabular} \\
\hline $\begin{array}{l}\text { Sarwal et al. } \\
2003\end{array}$ & $9 / 22$ & NA & NA & NA & NA & NA & NA & ACR & $\begin{array}{l}\geq 275 / \mathrm{HPF} \quad /<100 / \\
\text { HPF }\end{array}$ \\
\hline $\begin{array}{l}\text { Zarkhin et al. } \\
2008\end{array}$ & $17 / 15$ & $14.5 / 13$ & $47.1 / 33.3$ & $23.5 / 26.7$ & NA & $51.9 / 26.1$ & $5.8 / 5.2$ & AR & $\begin{array}{l}\geq 275 / \mathrm{HPF} /<100 / \\
\mathrm{HPF}\end{array}$ \\
\hline
\end{tabular}

DCD: deceased donor; DGF: delayed graft function; HPF: high power field; ACR: acute cellular rejection; AR: acute rejection; NA, not available

a: CD 20 positive group/CD 20 negative group

The main characteristics of the included studies are presented in Table 1. Panel-reactive antibodies (PRAs) $[4,9]$, human leukocyte antigen (HLA) mismatches [6, 7], B-cell flow cytometric crossmatches (B-FCXM) $[4,7]$ and induction therapy $[4,7]$ were reported in two studies, whereas cold ischemia time [4] and donor specific antibodies (DSAs) [6] were reported in one study. Primary kidney disease was not described in any study. Baseline immunosuppression and rejection treatments were presented differently among the articles $[4,7,9]$.

\section{Meta-analysis}

\section{C4d staining}

Three studies assessed the C4d staining of the peritubular capillaries in renal biopsies from 126 patients. There was no heterogeneity between the CD20-positive and CD20-negative groups $\left(\mathrm{I}^{2}=0 \%\right.$; Pheterogeneity
$=0.73)$. The fixed effects model was adopted, and no association was found between CD20+ B-cell infiltration and the C4d-positive staining of the peritubular capillaries during acute graft rejection (OR, 1.17; 95\% CI, 0.50-2.71) (Figure 2).

\section{Steroid resistance}

Steroid resistance was evaluated in 4 studies including 144 patients. In Hwang et al., 2010 and Hippen et al., 2005, acute rejection was treated with 3-4 daily boluses of intravenous methylprednisolone (500 $\mathrm{mg}$ /day), followed by a 5-7 days' oral steroid taper. If steroid resistance occured, additional treatment with antithymocyte globulin or muromonab-CD3 (OKT3) was given. However, the steroid doses weren't given in two other studies. An association between CD20+ B-cell infiltration and steroid resistance after transplant rejection

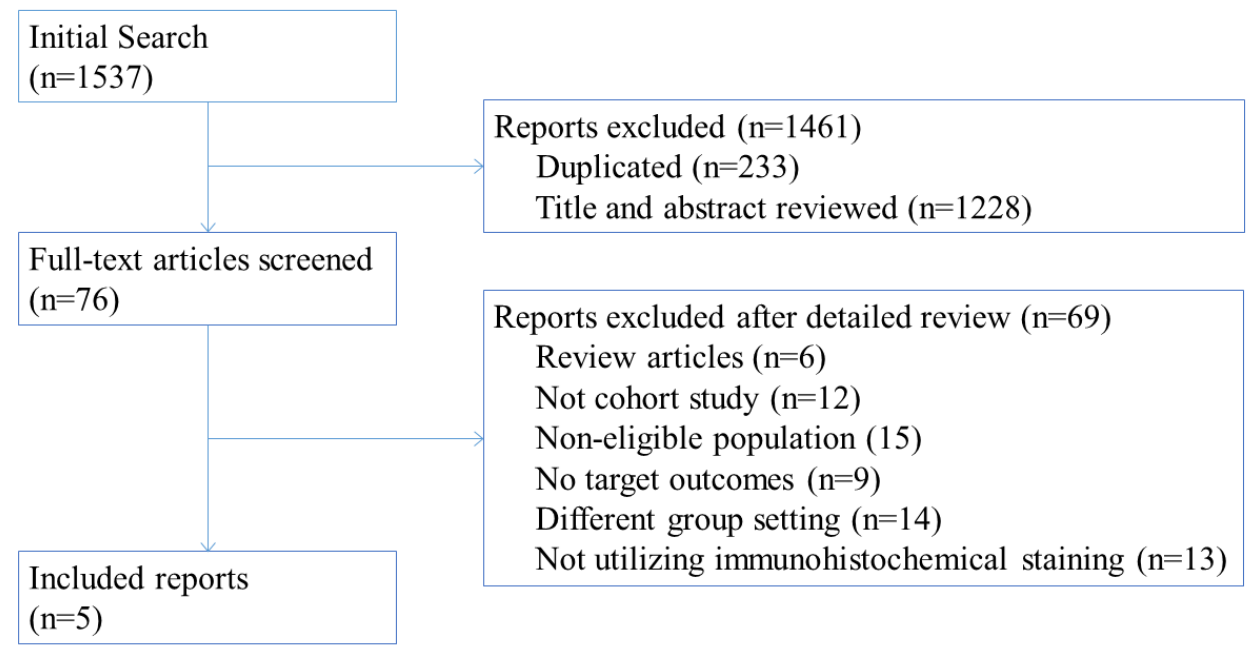

Figure 1: Flow chart of study selection. 
(OR, 30.17; 95\% CI, 9.77-93.16; $\mathrm{I}^{2}=0 \%$; Pheterogeneity $=0.64$ ) was found (Figure 3). CD20+ B-cell infiltration might account for the need for more courses of steroids for the treatment of rejection.

\section{Graft loss}

When all 5 studies, including 200 patients, were assessed, CD20+ B cell infiltration during rejection was associated with an increased risk of graft loss (odds ratio [OR], 2.68; 95\% CI, 1.43-5.02; I ${ }^{2}=46 \%$; Pheterogeneity $=0.11$ ) (Figure 4). Heterogeneity was explained by the different criteria for identifying "CD20-positive" versus "CD20-negative" biopsies included in these reports, as identified by a subgroup analysis. Three studies, including 117 patients, used a threshold cell count of more than 275 in the selected high power field (HPF) as the definition of CD20 positive. These studies showed an association between CD20+ cell infiltration during rejection and graft loss during follow up $[2,6,7]$ (OR, 5.37; 95\% CI, 2.25$12.78 ; \mathrm{I}^{2}=0 \%$; Pheterogeneity $=0.53$ ) (Figure 4$)$. No associations were found in the analysis of studies using other threshold definitions [4, 9] (OR, 1.05; 95\% CI, 0.39$2.83 ; \mathrm{I}^{2}=0 \%$; Pheterogeneity $\left.=0.41\right)$.

\section{Quality assessment results}

The details of the quality evaluation, based on the Newcastle-Ottawa Quality Assessment Scale for each study, are shown in Supplementary Table 1. Two studies were considered to be of moderate quality and three of high quality. The average score was 7.6.

Although the evidence demonstrated little risk of bias, consistency, and directness and no publication bias, all of the studies included were observational studies. Thus, the overall GRADE (Grading of Recommendations Assessment, Development and Evaluation) strength of the evidence was rated as low for graft loss. The strength of the evidence for steroid resistance was increased by the very large effect, but at the same time, it was decreased by the wide confidence intervals, and was therefore rated low as well (Supplementary Table 2). Further research is required to strengthen our confidence in the estimate of the effects.

\section{Sensitivity analyses}

The results remained unchanged after applying a random effect model or omitting each individual study.

\section{Publication bias}

Contour-enhanced funnel plots, Begg's regression test and Egger's regression test revealed no publication bias regarding graft loss (Begg's test, $P=0.806$; Egger's test, $P=280$ ) or steroid resistance (Begg's test, $P=0.734$; Egger's test, $P=0.220)$. The funnel plots for each metaanalysis are available in Supplementary Figures 1 and 2.

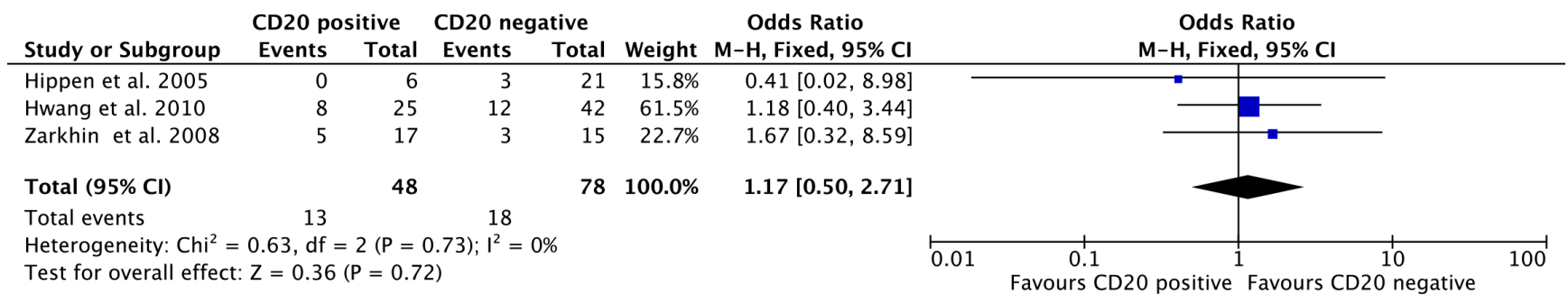

Figure 2: Meta-analysis of the incidence of C4d-positive staining between CD 20-positive and CD 20-negative groups. Abbreviations: CI, confidence interval; KH, Knapp-Hartung method.

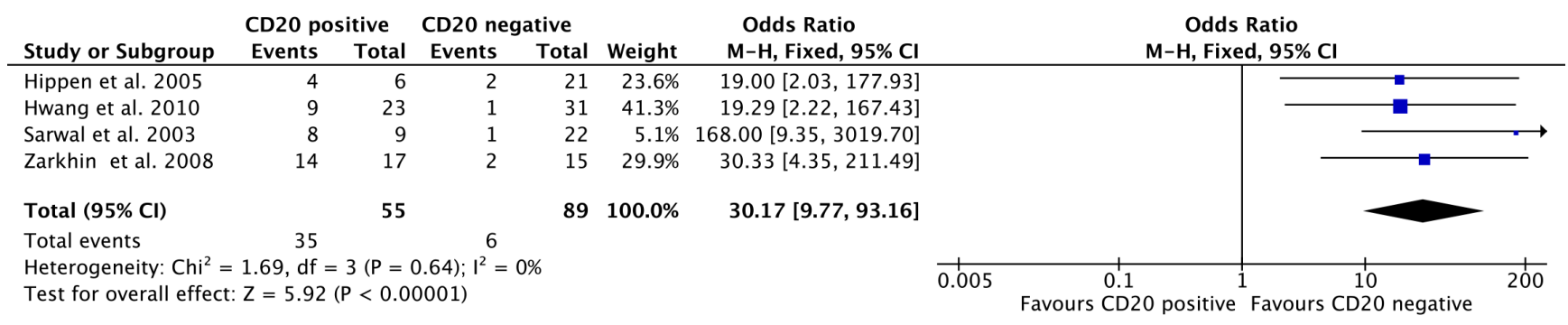

Figure 3: Comparison of the CD 20-positive group versus the CD 20-negative group for the incidence of steroidrecalcitrant graft rejection. Abbreviations: $\mathrm{CI}$, confidence interval; $\mathrm{KH}$, Knapp-Hartung method. 


\section{DISCUSSION}

To the best of our knowledge, the present metaanalysis is the first to explore the potential relationship between $\mathrm{CD} 20+\mathrm{B}$-cell infiltration and the outcomes of kidney graft after acute rejection. We found that the presence of $\mathrm{CD} 20+\mathrm{B}$ cells was a potential cause of more aggressive and steroid-recalcitrant graft rejection. It was also associated with poor graft outcomes. This may be related to the antibody-dependent and antibodyindependent roles of $\mathrm{B}$ cells. The latter includes the capacity to secrete inflammatory cytokines and chemokines [15-18], antigen presentation [19-21], T-cell and dendritic-cell regulation [22-26], as well as a role in lymphoid tissue development [27, 28]. Bagnasco et al. found that CD3-positive T cells and CD20-positive B cells were in the same infiltrate in some cases [9], and Hwang et al. found that the patients with $\mathrm{CD} 20+\mathrm{CD} 38+$ infiltration had poorer graft prognosis compared with patients with only CD20+ infiltrates [7]. These studies indicated that the interaction of $\mathrm{CD} 20+\mathrm{B}$ cells with other immune cells may account for the progress of graft inflammation. The complexity of differences in patient populations in the included studies cannot be overestimated, including different ethnicities, primary kidney diseases, surgical skill levels, immunosuppression protocols, intervals from transplantation to rejection, previous rejections and rejection etiologies. All of these factors could influence immunological processes and their downstream molecular and cellular responses. However, there was no sufficient information available in the included trials to conduct a meta-regression or subgroup analyses of these factors. In addition, a lack of standardized criteria for defining CD20positive and CD20-negative biopsies may have caused heterogeneity among the different studies. The subgroup analyses suggested that the presence of $\geq 275 \mathrm{CD} 20+$ cells /HPF was potentially a poor prognostic indicator. A difference was not revealed when other definitions of $\mathrm{CD} 20$ positive biopsies were used. However, taking $\geq 275 \mathrm{CD} 20+$ cells/HPF as a threshold in clinical is unwise, since only 3 studies with 117 participants proved the association. More studies with large sample size are needed to draw the conclusion.

$\mathrm{C} 4 \mathrm{~d}$ is one of the by-products of the classical complement activation pathway initiated by alloantibody production. Thus, linear $\mathrm{C} 4 \mathrm{~d}$ staining in peritubular capillaries indicates that rejection is humorally mediated $[30,31]$. However, the sensitivity and specificity of C4d staining alone as a diagnostic criterion for antibodymediated rejection (AMR) has been challenged in the Banff 2011 Meeting Report and Banff 2013 Meeting Report $[32,33]$. Histological evidence of acute tissue injury, serological evidence of DSAs, and other evidence of current/recent antibody interactions are needed to identify the immune mechanism. In the present study, an association of CD20+ B cell infiltration with C4d-positive staining in biopsies from patients experiencing renal rejection biopsies was not found. However, we could not exclude the attributable role of CD20+ cell infiltration in the conventional antibody-mediated rejection. Other stronger biomarkers of humoral rejection (such as DSA) are needed to reveal the relationship.

Although our systematic review and metaanalysis indicated that $\mathrm{CD} 20+$ cell infiltration is a risk factor for poor graft outcomes after acute rejection, this study has several limitations that should be considered. Subtle differences in the types of rejection described in the included trials, as shown in Table 1, might have

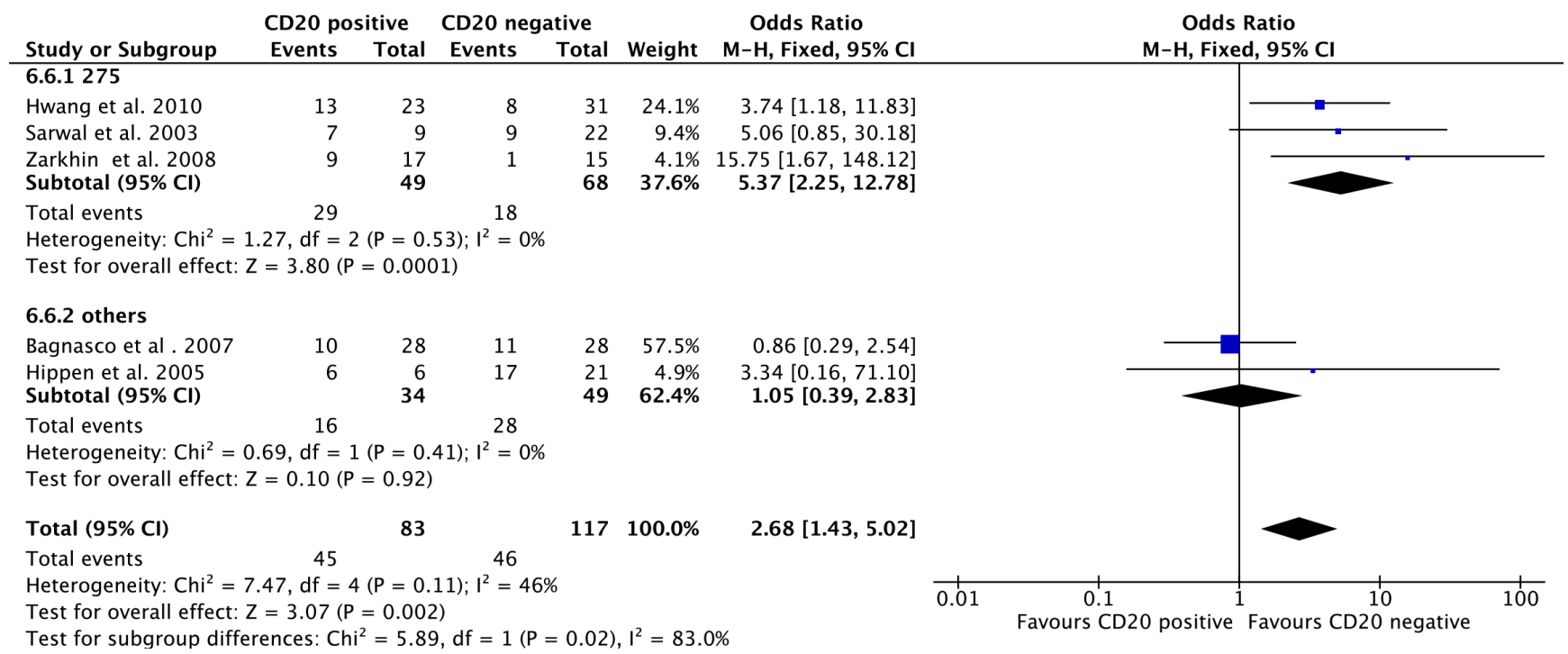

Figure 4: Meta-analysis of graft loss incidence between the CD 20-positive and CD 20-negative groups and subgroup analysis of studies based on different CD 20-positive definitions. Abbreviations: CI, confidence interval; KH, Knapp-Hartung method. 
affected the result. In addition, taking overall graft loss as a prognostic indicator may not be persuasive enough, since the follow-up lengths of the studies were not identical. However, there was no sufficient graftsurvival information at each time point to conduct a meta-analysis. Besides, the sample size was small, with only 200 participants evaluated, and the trials included were observational studies with low GRADE ratings. More persuasive evidence, such as that from randomized controlled trials (RCTs) with larger numbers of patients worldwide are needed. Nevertheless, the present study still verifies that the presence of CD20+ B cells in renal biopsies could be a predictive marker for worse allograft outcomes after transplant rejection.

\section{MATERIALS AND METHODS}

\section{Study design}

Studies that met the following eligibility criteria were included in this meta-analysis: 1) a cohort study; 2) the study participants had undergone acute rejection, defined by the Banff 1997 classification of allograft histopathology [34]; 3) they identified CD 20+ B-cell infiltration via immunohistochemical staining of renal biopsy samples from cases of rejection; and 4) the study reported the incidence of graft loss. The primary outcome was the incidence of graft loss during followup. The secondary outcomes were the incidence of steroid resistance and $\mathrm{C} 4 \mathrm{~d}$ staining of renal allografts during transplant rejection.

\section{Search strategy}

The MEDLINE, EMBAS, and Cochrane Library databases were searched through January 14, 2016, with no language or regional restrictions. The following Medical Subject Heading terms and text words and their synonyms were used: allograft rejection, kidney transplantation, graft outcome, and CD20. Titles and abstracts were independently screened by two investigators (QS, RW). If insufficient information was provided in the abstract regarding the inclusion and exclusion criteria, a full-text evaluation was performed by the same two authors to determine the eligibility of the study. Discrepancies were resolved by a third author (BL).

\section{Data extraction}

Data extraction was conducted independently by two investigators (ZC, HJ). The content extracted included the name of the first author, year of publication, follow-up length, and patient characteristics, such as age, sex, ethnicity, donor type (living or deceased), re-transplantation, PRAs, DSAs, HLA mismatches, B-FCXM, cold ischemia time, time post-transplantation, immunosuppressive therapy and outcomes of interest. Disagreements were resolved by reaching a consensus or via re-extraction of the data by a third person (YL).

The Newcastle-Ottawa Scale (NOS) Assessment for cohort studies [35] was applied to evaluate the quality of the studies by two independent reviewers (YL, BL). Three aspects were included: selection of cases and controls, comparability between them, and assessment of outcomes. Assessment of comparability was based on age, sex, ethnicity, and donor type. The total score ranged from 0 (lowest) to 9 (highest), with 5 or less deemed low quality, 6 or 7 deemed moderate quality, and 8 or 9 deemed high quality. Any discrepancies were addressed via discussion or by a third reviewer (JC).

The strength of evidence for each outcome was assessed using the GRADE guidelines [36]. The quality of evidence was rated as high, moderate, low, or very low according to the study characteristics as follow: limitations of the study design, inconsistencies, indirectness of evidence, imprecision, publication bias and other considerations.

\section{Data analysis}

A meta-analysis was performed to estimate the differences in outcomes between CD20-positive kidney recipients and CD20-negative recipients using REVIEW MANAGER software, version 5.1 (REVIEW MANAGER, REVMAN, Copenhagen, Denmark). The ORs with 95\% CIs were calculated using the Mantel-Haenszel equation in a fixed effects model. Potential heterogeneity was assessed using Cochran's Q-statistic test, with $P<0.1$ considered statistically significant, and the $\mathrm{I}^{2}$ test, with values $>50 \%$ indicative of high heterogeneity. To explain the cause of heterogeneity among studies, a subgroup analysis was conducted. A sensitivity analysis was performed using a random effects model by removing each study to assess the consistency and stability of the results. A funnel plot analysis was conducted to evaluate potential publication biases using Stata software, version 11.0 (Stata Inc., College Station, TX). Publication bias was further measured using Begg's and Egger's tests, with a threshold $P$ value of 0.1 considered statistically significant. The present study met the criteria of the Preferred Reporting Items for Systematic Reviews and Meta-Analyses (PRISMA) statement [37] (see data in Supplementary Checklist).

\section{ACKNOWLEDGMENTS}

The authors would like to thank Rending Wang for his review of the manuscript and Yi Shen for his assistance 
with conducting the statistical analysis.

\section{CONFLICTS OF INTEREST}

We declare that we have no conflicts of interests.

\section{REFERENCES}

1. Cole EH, Johnston O, Rose CL, Gill JS. Impact of acute rejection and new-onset diabetes on long-term transplant graft and patient survival. Clin J Am Soc Nephrol. 2008; 3:814-21.

2. Sarwal M, Chua MS, Kambham N, Hsieh SC, Satterwhite T, Masek M, Salvatierra O Jr. Molecular heterogeneity in acute renal allograft rejection identified by DNA microarray profiling. N Engl J Med. 2003; 349:125-38.

3. Tsai EW, Rianthavorn P, Gjertson DW, Wallace WD, Reed $\mathrm{EF}$, Ettenger RB. CD20+ lymphocytes in renal allografts are associated with poor graft survival in pediatric patients. Transplantation. 2006; 82:1769-73.

4. Hippen BE, DeMattos A, Cook WJ, Kew CE 2nd, Gaston RS. Association of CD20+ infiltrates with poorer clinical outcomes in acute cellular rejection of renal allografts. Am J Transplant. 2005; 5:2248-52.

5. Martins HL, Silva C, Martini D, Noronha IL. Detection of B lymphocytes (CD20+) in renal allograft biopsy specimens. Transplant Proc. 2007; 39:432-34.

6. Zarkhin V, Kambham N, Li L, Kwok S, Hsieh SC, Salvatierra O, Sarwal MM. Characterization of intra-graft B cells during renal allograft rejection. Kidney Int. 2008; 74:664-73.

7. Hwang HS, Song JH, Hyoung BJ, Lee SY, Jeon YJ, Kang SH, Chung BH, Choi BS, Choi YJ, Kim JI, Moon IS, Kim YS, Yang CW. Clinical impacts of CD38+ B cells on acute cellular rejection with CD20+ B cells in renal allograft. Transplantation. 2010; 89:1489-95.

8. Muorah MR, Brogan PA, Sebire NJ, Trompeter RS, Marks SD. Dense B cell infiltrates in paediatric renal transplant biopsies are predictive of allograft loss. Pediatr Transplant. 2009; 13:217-22.

9. Bagnasco SM, Tsai W, Rahman MH, Kraus ES, Barisoni L, Vega R, Racusen LC, Haas M, Mohammed BS, Zachary AA, Montgomery RA. CD20-positive infiltrates in renal allograft biopsies with acute cellular rejection are not associated with worse graft survival. Am J Transplant. 2007; 7:1968-73.

10. Kayler LK, Lakkis FG, Morgan C, Basu A, Blisard D, Tan HP, McCauley J, Wu C, Shapiro R, Randhawa PS. Acute cellular rejection with CD20-positive lymphoid clusters in kidney transplant patients following lymphocyte depletion. Am J Transplant. 2007; 7:949-54.

11. Doria C, di Francesco F, Ramirez CB, Frank A, Iaria M, Francos G, Marino IR, Farber JL. The presence of B-cell nodules does not necessarily portend a less favorable outcome to therapy in patients with acute cellular rejection of a renal allograft. Transplant Proc. 2006; 38:3441-44.

12. Eikmans M, Roos-van Groningen MC, Sijpkens YW, Ehrchen J, Roth J, Baelde HJ, Bajema IM, de Fijter JW, de Heer E, Bruijn JA. Expression of surfactant protein-C, S100A8, S100A9, and B cell markers in renal allografts: investigation of the prognostic value. J Am Soc Nephrol. 2005; 16:3771-86.

13. Carpio VN, Noronha IL, Martins HL, Jobim LF, Gil BC, Külzer AS, Loreto MS, Gonçalves LF, Manfro RC, Veronese FV. Expression patterns of B cells in acute kidney transplant rejection. Exp Clin Transplant. 2014; 12:405-14.

14. Viklicky O, Hribova P, Volk HD, Slatinska J, Petrasek J, Bandur S, Honsova E, Reinke P. Molecular phenotypes of acute rejection predict kidney graft prognosis. J Am Soc Nephrol. 2010; 21:173-80.

15. Harris DP, Haynes L, Sayles PC, Duso DK, Eaton SM, Lepak NM, Johnson LL, Swain SL, Lund FE. Reciprocal regulation of polarized cytokine production by effector $\mathrm{B}$ and T cells. Nat Immunol. 2000; 1:475-82.

16. Wojciechowski W, Harris DP, Sprague F, Mousseau B, Makris M, Kusser K, Honjo T, Mohrs K, Mohrs M, Randall T, Lund FE. Cytokine-producing effector B cells regulate type 2 immunity to H. polygyrus. Immunity. 2009; 30:42133.

17. Ring GH, Saleem S, Dai Z, Hassan AT, Konieczny BT, Baddoura FK, Lakkis FG. Interferon-gamma is necessary for initiating the acute rejection of major histocompatibility complex class II-disparate skin allografts. Transplantation. 1999; 67:1362-65.

18. Ishii D, Schenk AD, Baba S, Fairchild RL. Role of TNFalpha in early chemokine production and leukocyte infiltration into heart allografts. Am J Transplant. 2010; 10:59-68.

19. Crawford A, Macleod M, Schumacher T, Corlett L, Gray D. Primary $\mathrm{T}$ cell expansion and differentiation in vivo requires antigen presentation by B cells. J Immunol. 2006; 176:3498-506.

20. Noorchashm H, Reed AJ, Rostami SY, Mozaffari R, Zekavat G, Koeberlein B, Caton AJ, Naji A. B cellmediated antigen presentation is required for the pathogenesis of acute cardiac allograft rejection. J Immunol. 2006; 177:7715-22.

21. Giles JR, Kashgarian M, Koni PA, Shlomchik MJ. B Cell-Specific MHC Class II Deletion Reveals Multiple Nonredundant Roles for B Cell Antigen Presentation in Murine Lupus. J Immunol. 2015; 195:2571-79.

22. Lund FE, Randall TD. Effector and regulatory B cells: modulators of CD4+ T cell immunity. Nat Rev Immunol. 2010; 10:236-47.

23. Shen H, Whitmire JK, Fan X, Shedlock DJ, Kaech SM, Ahmed R. A specific role for B cells in the generation of CD8 $\mathrm{T}$ cell memory by recombinant Listeria 
monocytogenes. J Immunol. 2003; 170:1443-51.

24. Ng YH, Oberbarnscheidt MH, Chandramoorthy HC, Hoffman R, Chalasani G. B cells help alloreactive T cells differentiate into memory T cells. Am J Transplant. 2010; 10:1970-80.

25. Martin F, Chan AC. Pathogenic roles of B cells in human autoimmunity; insights from the clinic. Immunity. 2004; 20:517-27.

26. Martin F, Chan AC. B cell immunobiology in disease: evolving concepts from the clinic. Annu Rev Immunol. 2006; 24:467-96.

27. Kerjaschki D, Regele HM, Moosberger I, Nagy-Bojarski K, Watschinger B, Soleiman A, Birner P, Krieger S, Hovorka A, Silberhumer G, Laakkonen P, Petrova T, Langer B, Raab I. Lymphatic neoangiogenesis in human kidney transplants is associated with immunologically active lymphocytic infiltrates. J Am Soc Nephrol. 2004; 15:603-12.

28. Thaunat O, Field AC, Dai J, Louedec L, Patey N, Bloch MF, Mandet C, Belair MF, Bruneval P, Meilhac O, Bellon B, Joly E, Michel JB, Nicoletti A. Lymphoid neogenesis in chronic rejection: evidence for a local humoral alloimmune response. Proc Natl Acad Sci USA. 2005; 102:14723-28.

29. Nickeleit V, Andreoni K. The classification and treatment of antibody-mediated renal allograft injury: where do we stand? Kidney Int. 2007; 71:7-11.

30. Colvin RB, Smith RN. Antibody-mediated organ-allograft rejection. Nat Rev Immunol. 2005; 5:807-17.

31. Nankivell BJ, Alexander SI. Rejection of the kidney allograft. N Engl J Med. 2010; 363:1451-62.
32. Mengel $\mathrm{M}$, Sis $\mathrm{B}$, Haas $\mathrm{M}$, Colvin RB, Halloran PF, Racusen LC, Solez K, Cendales L, Demetris AJ, Drachenberg CB, Farver CF, Rodriguez ER, Wallace WD, et al. Banff 2011 Meeting report: new concepts in antibodymediated rejection. Am J Transplant. 2012; 12:563-70.

33. Haas M, Sis B, Racusen LC, Solez K, Glotz D, Colvin RB, Castro MC, David DS, David-Neto E, Bagnasco SM, Cendales LC, Cornell LD, Demetris AJ, et al. Banff 2013 meeting report: inclusion of c4d-negative antibodymediated rejection and antibody-associated arterial lesions. Am J Transplant. 2014; 14:272-83.

34. Racusen LC, Solez K, Colvin RB, Bonsib SM, Castro MC, Cavallo T, Croker BP, Demetris AJ, Drachenberg CB, Fogo AB, Furness P, Gaber LW, Gibson IW, et al. The Banff 97 working classification of renal allograft pathology. Kidney Int. 1999; 55:713-23.

35. Stang A. Critical evaluation of the Newcastle-Ottawa scale for the assessment of the quality of nonrandomized studies in meta-analyses. Eur J Epidemiol. 2010; 25:603-05.

36. Balshem H, Helfand M, Schünemann HJ, Oxman AD, Kunz R, Brozek J, Vist GE, Falck-Ytter Y, Meerpohl J, Norris S, Guyatt GH. GRADE guidelines: 3. Rating the quality of evidence. J Clin Epidemiol. 2011; 64:401-06.

37. Moher D, Liberati A, Tetzlaff J, Altman DG; PRISMA Group. Preferred reporting items for systematic reviews and meta-analyses: the PRISMA statement. PLoS Med. 2009; 6:e1000097. 